\section{Tinjauan Pustaka}

\title{
POTENSI EKSTRAK BUNGA KAMBOJA (PLUMERIA SP.) DAN BUNGA KLUWIH (ARTOCARPUS CAMANSI) SEBAGAI BIOLARVASIDA NYAMUK ANOPHELES SP. DALAM UPAYA PENCEGAHAN PENYAKIT MALARIA
}

\author{
Luh Gde Sri Adyani Suari, ${ }^{1}$ Abiyyu Didar Haq, ${ }^{1}$ Luh \\ Ade Dita Rahayu ${ }^{1}$
}

\author{
${ }^{1}$ Program Studi Pendidikan Dokter, Fakultas \\ Kedokteran, Universitas Mataram, Mataram
}

\section{ABSTRAK}

Pendahuluan: Malaria merupakan salah satu permasalahan kesehatan yang menjadi perhatian di berbagai negara, terutama di Indonesia yang merupakan negara dengan iklim tropis. Untuk meminimalkan penularan malaria maka dilakukan upaya pengendalian terhadap Anopheles sp. sebagai vektor malaria. Beberapa upaya pengendalian vektor yang dilakukan misalnya dilakukan larviciding. Insektisida konvensional seperti malathion, DDT dan piretroid yang umumnya digunakan untuk pengendalian vektor, diketahui menyebabkan masalah seperti polusi lingkungan, efek residu dan resistensi pada spesies nyamuk. Maka dari itu, diperlukan solusi alternatif dari penggunaan insektisida yang berlebihan agar lebih aman dan ramah lingkungan. Salah satu tanaman yang berpotensi dijadikan larvasida alami yaitu bunga kamboja dan bunga kluwih.

Metode: Tinjauan pustaka ini menggunakan berbagai bentuk sumber yang didapatkan dari portal publikasi daring antara lain National Center for Biotechnology Information (NCBI), Garba Rujukan Digital (GARUDA), serta Google Scholar.

Pembahasan: Ekstrak bunga Plumeria sp. menunjukkan adanya steroid, alkaloid, flavonoid, glikosida, tanin dan minyak atsiri. Senyawa steroid, flavonoid, dan alkaloid merupakan beberapa senyawa yang diperkirakan memiliki efek larvisida. Steroid dapat menghambat pertumbuhan serangga yaitu perubahan dari stadium larva ke pupa dan sebaliknya. Flavonoid bekerja sebagai racun pernapasan. Alkaloid berperan sebagai racun kontak dan menghambat acetylcholinesterase, menimbulkan rasa pahit sehingga mengganggu proses pengambilan makan oleh larva. Sedangkan Artocarpus camansi mengandung senyawa seperti saponin, flavonoid, polifenol, yang memiliki efek mekanisme berurutan yaitu penghambat rangsang makan serangga, inhibitor pernafasan, hormon penghambat moulting.

Simpulan: Kombinasi ekstrak bunga kamboja (Plumeria sp.) dan bunga kluwih (Artocarpus camansi) memiliki potensi untuk digunakan sebagai biolarvasida nyamuk Anopheles sp.

Kata Kunci: Artocarpus camansi, Biolarvasida, Malaria, Plumeria sp. 


\title{
THE POTENTIAL OF KAMBOJA (PLUMERIA SP.) AND KLUWIH (ARTOCARPUS CAMANSI) FLOWER EXTRACT AS A BIOLARVACIDE OF ANOPHELES SP. IN AN ATTEMPT TO PREVENT MALARIA
}

\begin{abstract}
Background: Malaria is one of many health problem that attracts attention in a lot of countries, especially Indonesia as a tropical country. To minimalize the spread of malaria, many efforts is done to control Anopheles sp as the vector of malaria. Some of many effort that has been done to control malaria is larvaciding. Conventional insecticide such as malathion, $D D T$, and pyrethroid that is widely used for vector control is known to cause problem such as pollution, residual effect, and resistance of the mosquitoes. Therefore, it is urged to find an alternative of the overuse of insecticide and find a better and safer solution both for us and for the environment

Methods: This literature review used a variety of sources that are being retrieved from online publication portal such as National Center for Biotechnology Information (NCBI), Garba Rujukan Digital (GARUDA), and Google Scholar.

Discussion: Extract of Plumeria sp. 's flower showed the existance of steroid, alkaloid, flavonoid, glycoside, tannin, and essential oil. Steroid, flavonoid, and alkaloid substance are the substances that is expected to have the larvicidal effect. Steroid is able to restrict insect's growth in the transition phase from larvae to pupae and vice versa. Flavonoid works as a respiratory toxin. Alkaloid acts as a contact toxic and inhibits the acetylcholinesterase which will cause a bitter taste which then interrupts the mealtime of the larvae. Meanwhile Artocarpus camansi contains a substances such as saponin, flavonoid, and polyphenol whose effect is lowering the appetite, inhibiting the respiratory system, and inhibiting the moulting hormone.
\end{abstract}

Conclusion: The combination of kamboja flower (Plumeria sp.) and kluwih flower (Artocarpus camansi) has a potential to be used as biolarvacide of Anopheles sp.

Keywords: Artocarpus camansi, Biolarvacide, Malaria, Plumeria sp.

\section{PENDAHULUAN}

Malaria merupakan salah satu permasalahan kesehatan yang menjadi perhatian banyak negara di seluruh dunia. Penyakit ini merupakan penyakit yang disebabkan oleh parasit dan menyebar melalui gigitan nyamuk yang sudah terinfeksi oleh parasit.[1] Penyakit malaria ini disebabkan oleh parasit Plasmodium yang ditularkan melalui gigitan nyamuk Anopheles betina. ${ }^{[2]}$ Nyamuk Anopheles ini sering dijumpai pada daerah tropis dan subtropis karena memiliki kelembaban udara dan curah hujan yang cukup untuk keberlangsungan hidup nyamuk. [3]

Penyakit malaria masih ditemukan di seluruh provinsi di Indonesia. Berdasarkan API, dilakukan stratifikasi wilayah dimana Indonesia bagian Timur masuk dalam stratifikasi malaria tinggi, stratifikasi sedang di beberapa wilayah di
Kalimantan, Sulawesi dan Sumatera sedangkan di Jawa-Bali masuk dalam stratifikasi rendah, meskipun masih terdapat desa/fokus malaria tinggi.[4]

Dari gambar 1 didapatkan bahwa API dari tahun 2008 - 2009 menurun dari 2,47 per 1000 penduduk menjadi 1,85 per 1000 penduduk. Namun, bila dilihat per provinsi status endemisitas yang tinggi masih terjadi di beberapa daerah yaitu Papua Barat, NTT dan Papua terdapat 12 provinsi yang diatas angka API nasional. [5]

World Malaria Report pada tahun 2015 menyebutkan bahwa penyakit malaria telah menyerang 106 negara di dunia, sehingga penyakit ini dijadikan sebagai tujuan bersama yang harus dicapai sebagai komitmen global pada Sustanaible Development Goals (SDGs). ${ }^{[5]} \mathrm{Hal}$ ini tertuang dalam tujuan nomor 3, yakni kesehatan yang baik dan 


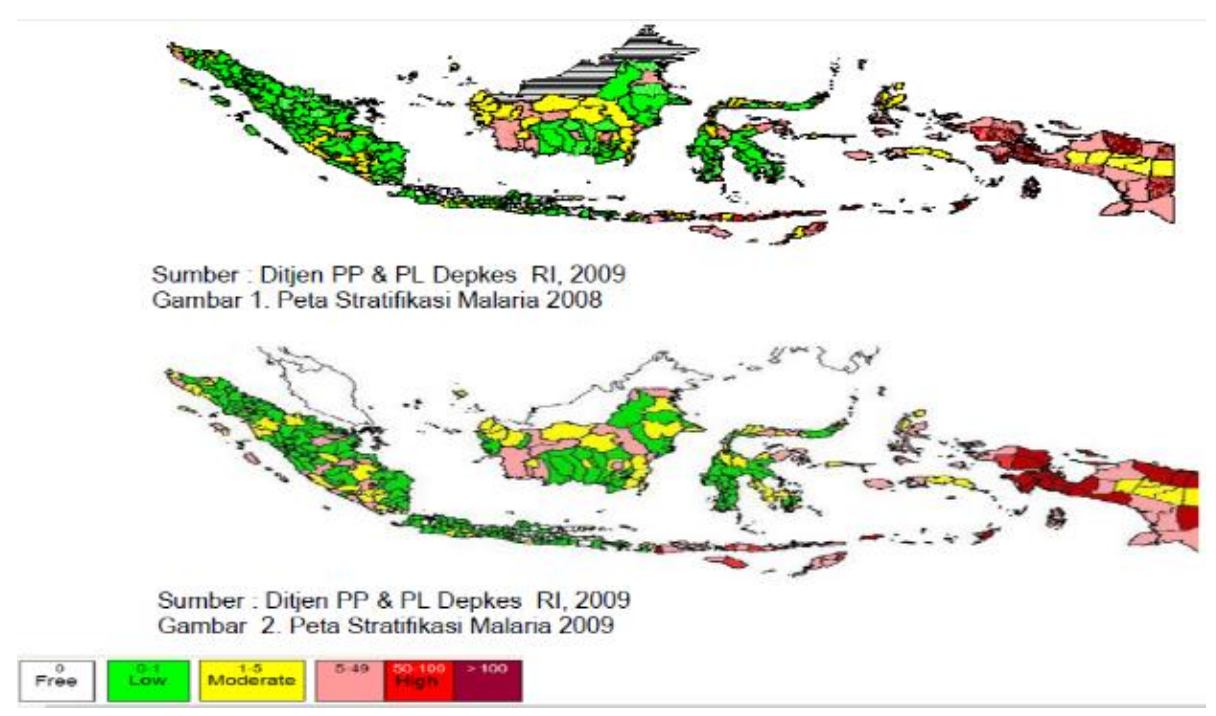

Gambar 1. Peta Stratifikasi Malaria ${ }^{4}$

kesejahteraan, tepatnya pada tujuan 3.3 dalam SDGs. ${ }^{[6]}$ Eliminasi malaria pada akhirnya akan berkaitan dengan pencapaian beberapa poin lainnya dalam SDGs. Eliminasi malaria akan memutus siklus penyakit dan kemiskinan yang saling berkaitan sesuai dengan tujuan pertama dalam SDGs. [7] Eliminasi malaria juga akan meningkatkan produktivitas manusia sehingga turut berkontribusi dalam pencapaian tujuan kedua SDGs, yakni mengakhiri kelaparan, dan tujuan keempat, yakni memastikan pendidikan yang berkualitas. ${ }^{[7]}$ Eliminasi malaria di dunia juga berkaitan dengan tujuan SDGs nomor 17 tentang penguatan kemitraan global karena negara di dunia tidak dapat memerangi malaria tanpa adanya kerjasama.[7]

Pemerintah Indonesia saat ini tengah memberikan perhatian khusus terhadap penyakit malaria yang hingga saat ini menjadi ancaman bagi status kesehatan masyarakat terutama bagi rakyat yang hidup di daerah terpencil. Hal Salah satu bentuk perhatian khusus tersebut adalah dengan dikeluarkannya Keputusan Menteri Kesehatan Republik Indonesia

Nomor 293/MENKES/SK/IV/2009 menyusun strategi dengan melaksanakan program eliminasi malaria secara bertahap hingga terealisasi di seluruh nusantara demi terwujudnya masyarakat yang hidup sehat dengan terbebas dari penularan malaria selambat-lambatnya tahun 2030.8] Upaya yang dilakukan dalam percepatan eliminasi malaria antara lain dengan pemberian kelambu anti nyamuk bagi daerah endemis tinggi. Sedangkan kelambu anti nyamuk di daerah endemi sedang diberikan kepada kelompok berisiko tinggi seperti ibu hamil dan bayi. Selain itu, tujuan spesifik dari percepatan eliminasi malaria juga mencakup peningkatan pemeriksaan darah dan pengobatan penderita secara tepat, penyemprotan rumah dengan target pada desa dengan kategori endemis tinggi, peningkatan kemampuan dan keterampilan sumber daya manusia yang terlibat dalam pelaksanaan pengendalian malaria. ${ }^{[8]}$

Meskipun berbagai strategi telah dicanangkan oleh pemerintah sebagai bentuk keseriusan dalam mengatasi malaria, angka kejadian kasus malaria masih mengalami peningkatan. Hal ini diakibatkan oleh program pemerintah yang cenderung fokus terhadap pemutusan rantai penluaran malaria sehingga penanggulangan penularan oleh nyamuk belum maksimal..8] Selain itu, program pemerintah dalam percepatan eliminasi malaria di Indonesia harus menghadapi berbagai tantangan, salah satunya adalah variasi yang tinggi pada tingkat endemisitas malaria menurut kabupaten/kota, kecapatan, desa, hingga dusun. ${ }^{[4]}$ 
Keberagaman endemisitas malaria diperburuk oleh posisi geografis Indonesia yang berada di antara benua Asia dan Australia sebagai habitat dari nyamuk penular malaria serta berbatasan langsung dengan negara yang memiliki tingkat endemisitas malaria yang tinggi. ${ }^{[4]}$

Untuk meminimalkan penularan malaria maka dilakukan upaya pengendalian terhadap Anopheles $s p$ sebagai nyamuk penular malaria. Beberapa upaya pengendalian vektor yang dilakukan misalnya terhadap jentik dilakukan larviciding (tindakan pengendalian larva Anopheles sp secara kimiawi, menggunakan insektisida), biological control (menggunakan ikan pemakan jentik), manajemen lingkungan, dan lain-lain. Pengendalian terhadap nyamuk dewasa dilakukan dengan penyemprotan dinding rumah dengan insektisida (IRS/ indoors residual spraying) atau menggunakan kelambu berinsektisida. ${ }^{[4]}$

Insektisida konvensional seperti malathion, DDT dan piretroid yang umumnya digunakan untuk pengendalian vektor, diketahui menyebabkan masalah seperti polusi lingkungan, efek residu dan resistensi pada spesies nyamuk. ${ }^{[12]}$

Resistensi insektisida yang saat ini terjadi misalnya resistensi insektisida karbamat yang terjadi pada populasi nyamuk Anopheles gambiae s.s. yang juga sebelumnya resistensi terhadap insektisida DDT, Permetrin, dan Piretroid.[19] Secara umum, terjadinya resistensi dipengaruhi beberapa faktor, utamanya penggunaan insektisida yang lama dan dosis yang tidak tepat. Resistensi ini dapat menyebabkan pengendalian vektor menjadi tidak efektif.[19]

Masalah selanjutnya, insektisida kimia yang digunakan dapat memiliki efek buruk pada kesehatan manusia dan lingkungan. Toksisitas insektisida bisa terjadi melalui beberapa mekanisme yaitu neurotoksisitas, pembentukan Reactive Oxygen Species (ROS), serta munculnya efek karsinogenik, teratogenic, dan genotoksik. ${ }^{[21]}$ Faktanya rata-rata angka kematian yang disebabkan oleh keracunan insektisida adalah sebesar 5,35 per 100.000 populasi sedangkan rata rata angka kejadian keracunan insektisida adalah sebesar 15,4 per 100.000 populasi.[22] Insektisida juga sangat berdampak negatif pada proses embriogenesis yang akan menimbulkan malformasi struktur tubuh dari embrio.[23]

Maka dari itu, kita harus mencari alternatif dari penggunaan insektisida/larvasida kimia yang berlebihan, mencari alternatif dan langkah-langkah kontrol yang lebih aman terutama dari sumber tanaman yang molekul turunannya ramah lingkungan, dapat terurai secara biologis (biodegradable).[24] Maka mulai banyak penelitian yang meneliti mengenai berbagai potensi dan efektivitas bahan alam sebagai larvasida alami bagi nyamuk vektor penyakit seperti Aedes aegypti maupun Anopheles. Penggunaan larvisida alami ini diharapkan tidak mempunyai efek samping terhadap lingkungan, manusia, dan tidak menimbulkan resistensi bagi larva

Salah satu tanaman yang dapat dijadikan larvasida alami yaitu bunga kamboja dan bunga kluwih. Bunga kamboja merupakan salah satu jenis bunga yang banyak ditanam di Indonesia, khususnya pulau Jawa dan Bali. Bunga kamboja juga seringkali digunakan untuk upacara keagamaan oleh masyarakat Bali.

Ekstrak bunga Plumeria alba dan Plumeria rubra menunjukkan adanya steroid, alkaloid, flavonoid, glikosida, tanin dan karbohidrat.[25] Senyawa steroid, flavonoid, dan alkaloid merupakan beberapa senyawa aktif yang diperkirakan memiliki efek larvisida. ${ }^{25}$ Sedangkan bunga kluwih mengandung senyawa-senyawa seperti saponin, flavonoid, polifenol, yang memiliki efek mekanisme berurutan yaitu penghambat rangsang makan serangga, inhibitor pernafasan, hormon penghambat moulting.[26]

Bunga kluwih banyak digunakan sebagai obat nyamuk bakar oleh masyarakat Bali, biasanya bunga ini didapatkan dari pohon Timbul, bunga ini berwarna kecoklatan, tekstur kering dan berbentuk memanjang, biasanya akan menjadi limbah karena jarang dimanfaatkan. Namun, saat digunakan sebagai obat nyamuk bakar, asap yang 
ditimbulkan dari pembakaran bunga kluwih ini sangat banyak.

Berdasarkan kekurangan dan gap yang terdapat dalam penggunaan insektisida saat ini pada penanggulangan dan pencegah penyakit malaria, maka penulis memiliki suatu gagasan yang diharapkan dapat melengkapi dan sebagai alternatif dari insektisida yang sudah ada saat ini, sehingga upaya penanggulangan dan pencegahan malaria di Indonesia dapat dilaksanakan dengan lebih efektif. Adapun konsep gagasan yang penulis ajukan adalah dengan membuat suatu kombinasi ekstrak bunga kamboja (Plumeria sp.) dan bunga kluwih (Artocarpus camansi) sebagai biolarvasida terhadap nyamuk Anopheles sp.

\section{METODE}

Tinjauan pustaka ini menggunakan berbagai jenis sumber antara lain sebanyak 22 artikel dalam jurnal ilmiah dan 10 laporan resmi pemerintah maupun instansi terkait. Pencarian artikel dilakukan di portal daring publikasi jurnal seperti National Center for Biotechnology Information (NCBI), Garba Rujukan Digital (GARUDA), serta Google Scholar. Adapun kata kunci yang digunakan adalah Artocarpus camansi, Biolarvasida, Malaria, Plumeria sp.

\section{PEMBAHASAN}

\subsection{Mekanisme Resistensi Insektisida}

Secara umum, resistensi terhadap insektisida pada serangga didasari oleh tiga mekanisme yaitu (1) penurunan sensitivitas target site, (2) perubahan lapisan kutikula yang mengurangi penetrasi senyawa insektisida ke tubuh serangga dan (3) peningkatan enzim detoksifikasi.[13] Resistensi yang terjadi ini tentu akan sangat mempengaruhi upaya memberantas vektor malaria. Dengan adanya resistensi ini, maka akan membuat vektor malaria lebih sulit untuk dikontrol. Penelitian pada tahun 2014 melaporkan bahwa rasio resistensi terhadap insektisida telah mencapai 2947 kali lipat. $^{[12]}$

Adanya peningkatan enzim esterase mengindikasikan adanya mekanisme detoksifikasi metabolis di dalam tubuh serangga. Esterase merupakan salah satu enzim detosifikasi yang diketahui berperan dalam mekanisme resisten serangga terhadap insektisida dari golongan organophosphat. Esterase digolongkan dalam kelompok enzim hidrolase, salah satu kelompok besar enzim yang mengkatalisis reaksi hidrolisa dari senyawa alifatik, ester aromatik, ester kolin dan organophosphorus. Malathion yang merupakan insektisida dari golongan organofosfat memiliki dua gugus ester carboxylic acid, sehingga senyawa ini dapat dihidrolisis oleh enzim karboksil esterase. Enzim karboksil esterase bisa menghidrolisis salah satu atau kedua gugus karboksilat yang menyusun senyawa malathion. Apabila gugus karboksilat penyusun senyawa malathion mengalami perubahan, maka senyawa insektisida ini akan kehilangan fungsinya. Resistensi yang disebabkan karena aktivitas enzim terjadi pada saat enzim tersebut menghalangi senyawa insektisida untuk mencapai sisi targetnya. ${ }^{[14]}$

Pada saat terjadi penghambatan enzim oleh karena penurunan sensitivitas pada sistem saraf dan aktivitas enzim asetilkolinesterase dalam tubuh serangga, maka jumlah asetilkolin meningkat dan berikatan dengan reseptor muskarinik dan nikotinik pada system syaraf pusat dan perifer. Hal tersebut mengakibatkan gejala keracunan pada seluruh tubuh serangga. Apabila terjadi mekanisme penurunan sensitivitas enzim asetilkolinesterase maka terjadi pula penurunan sensitivitas serangga terhadap insektisida sehingga serangga menjadi resisten. ${ }^{[15]}$

Adapun insektisida golongan piretroid yang lebih dikenal dengan synthetic pyretroid, bekerja dengan cara mengganggu sistem saraf.[16] Piretroid sintetik merupakan racun akson (serabut saraf) yang terikat pada voltage-gate sodium channel, yang mencegah penutupan kanal secara normal dan berakibat terjadinya rangsangan syaraf berkelanjutan sehingga serangga target mengalami kelumpuhan hingga mengalami kematian. ${ }^{[17]}$

Pada umumnya serangga juga mempunyai kemampuan adaptasi terhadap paparan insektisida, diantaranya dengan perubahan perilaku untuk menghindari paparan, mengurangi permeabilitas kutikula pada kulit, 
meningkatkan laju pengeluaran (ekskresi) bahan aktif dari dalam tubuh serangga, dan mengurangi sensitivitas terhadap insektisida. [18]

Adanya timbunan lemak juga dapat meningkatkan kecenderungan resistensi serangga terhadap insektisida karena menyebabkan penurunan penetrasi insektisida (toksikan) kearah situs aktif, sehingga sifat racun insektisida menurun. [15]

\subsection{Potensi Bunga Kamboja Sebagai \\ Biolarvasida}

Kamboja atau umumnya dikenal sebagai "Frangipani" adalah spesies pohon hias yang menghasilkan bungabunga yang harum. Tanaman ini berasal dari Meksiko, Amerika Tengah, Kolombia dan Venezuela tetapi banyak dibudidayakan di negara-negara tropis dan subtropis. ${ }^{[27]}$

Tabel 1. Aktivitas Farmakologis Plumeria rubra ${ }^{27}$

\begin{tabular}{|c|c|}
\hline $\begin{array}{c}\text { Aktivitas } \\
\text { Farmakologis }\end{array}$ & Senyawa Terkait \\
\hline Antibakterial & \multirow{11}{*}{$\begin{array}{l}\text { Plumericin, } \\
\text { isoplumericin }\end{array}$} \\
\hline Antifungal & \\
\hline Antimicrobial & \\
\hline Antialgal & \\
\hline Larvicidal & \\
\hline Molluscidal & \\
\hline Piscidal & \\
\hline Nematicidal & \\
\hline Antioksidatif & \\
\hline Hipolipidemik & \\
\hline Proteolitik & \\
\hline Sitotoksin & $\begin{array}{l}\text { Pulvoplumierin, } \\
\text { allamcin, } \\
\text { allamandin, } \\
\text { plumericin }\end{array}$ \\
\hline
\end{tabular}

Sejumlah

penelitian farmakologis praklinis dilakukan untuk menjelaskan bioaktivitasnya seperti yang telah tertera pada tabel diatas. Aktivitas farmakologis tersebut antara lain : aktivitas antibakteri, antijamur, antivirus, antialga, larvasidal, moluskisida, piscicidal, nematicidal, antioksidan dan penangkal radikal bebas, hipolipidemia, proteolitik, antikanker, sifat abortifacient.[27]

Dalam penelitian Maulidah (2016) mengenai pengaruh pemberian ekstrak daun kamboja putih (Plumeria alba) terhadap mortalitas larva Aedes aegypti, dimana sampel yang digunakan adalah larva Aedes aegypti instar III/IV sebanyak 240 ekor, dengan 6 perlakuan (0\%, 5\%, 7\%, $9 \%, 11 \%$ dan 13\%) sebanyak 4 kali pengulangan. Hasil penelitian menunjukkan bahwa ada pengaruh pemberian ekstrak daun kamboja putih (Plumeria alba) terhadap yaitu pada konsentrasi tertinggi 13\% dengan rata-rata mortalitas nyamuk sebanyak $96,25 \% .^{[15]}$

Dalam penelitian Rohman (2018), mengenai ekstrak bunga kamboja (Plumeria acuminata) pada larva Aedes aegypti. Hasil yang didapat dari penelitian ini yaitu pada konsentrasi $0,125 \%$ larva yang mati sebanyak 25 larva dari 100 larva dengan persentase $25 \%$, pada konsentrasi $0,25 \%$ larva yang mati sebanyak 35 larva dari 100 larva dengan persentase $35 \%$, pada konsentrasi $0,5 \%$ larva yang mati sebanyak 50 larva dari 100 larva dengan persentase $50 \%$, pada konsentrasi $1 \%$ larva yang mati sebanyak 77 larva dari 100 larva dengan persentase $77 \%$. Kesimpulan bahwa Ekstrak bunga kamboja (Plumeria acuminata) mampu membunuh larva Aedes aegy mampu membunuh larva Aedes aegypti.[16]

Ekstrak etanol daun kamboja mengandung senyawa aktif saponin, alkaloid, flavonoid dan polifenol. Senyawa-senyawa aktif tersebut mampu menghambat pertumbuhan larva nyamuk Aedes aegypti L.[28]

Pernyataan ini juga didukung oleh penelitian yang menguji fitokimia awal yang dilakukan pada ekstrak bunga Plumeria alba dan Plumeria rubra menunjukkan adanya steroid, alkaloid, flavonoid, glikosida, tanin dan karbohidrat dalam ekstrak bunga. ${ }^{[25]}$ Beberapa senyawa aktif yang diperkirakan memiliki efek larvisida adalah steroid, flavonoid, dan alkaloid.[25] Steroid dapat menghambat pertumbuhan serangga yaitu perubahan dari stadium larva ke pupa dan dari pupa ke nyamuk dewasa. Dengan adanya penambahan steroid yang berasal dari luar akan berpengaruh pada penebalan kitin pada dinding sel tubuh larva, sehingga pertumbuhan larva menjadi abnormal.[29]

Flavonoid adalah senyawa yang bersifat non polar, menghambat daya makan larva, dan bersifat toksik. Flavonoid bekerja sebagai inhibitor kuat 
pernapasan atau racun pernapasan dengan masuk ke dalam tubuh larva melalui sistem pernapasan sehingga menimbulkan kelayuan pada syaraf serta kerusakan pada sistem pernapasan dan mengakibatkan larva tidak bisa bernapas. ${ }^{[29]}$

Fungsi flavonoid berperan sebagai racun pernapasan atau inhibitor, ketika nyamuk melakukan pernapasan flavonoid akan masuk bersama udara $\left(\mathrm{O}_{2}\right)$ melalui alat pernapasanya kemudian flavonoid menghambat sistem kerja pernapasan di dalam tubuh larva nyamuk. Selain itu, kandungan antinyamuk lain dalam bunga kamboja yaitu minyak atsiri, minyak atsiri merupakan bahan aktif yang mempunyai kemampuan daya tolak terhadap gigitan nyamuk, kandungan kimia dalam minyak atsiri yang berfungsi sebagai repellent mengandung senyawa geraniol dan sitrenol sebanyak $75-80 \%$ dan bahanbahan lainya seperti linalool dan terpineol. Senyawa geraniol dan sitronelool memiliki bau yang menyengat dan harum yang tidak disukai oleh nyamuk. ${ }^{[30]}$

Alkaloid berperan sebagai racun
kontak dan menghambat acetylcholinesterase, menimbulkan rasa pahit sehingga mengganggu proses pengambilan makan oleh larva dan mengganggu sistem pernapasan maupun sistem saraf larva melalui aksi toksik. [29]

\subsection{Potensi Bunga Kluwih Sebagai Biolarvasida}

Dalam penelitian mengenai potensi ekstrak bunga jantan kluwih sebagai pembasmi larva nyamuk Aedes aegypti didapatkan hasil bahwa ekstrak bunga jantan kluwih memiliki potensi sebagai larvasida nyamuk Aedes aegypti pada ekstrak air dan butanol dengan nilai LC50 pada fase air $1 \%$, dan pada fase butanol 0,25\%.[31]

Penelitian aktivitas larvasida dari bunga jantan kluwih ini meliputi beberapa tahap yaitu: pengumpulan sampel (limbah bunga jantan keluwih), uji fitokimia, ekstraksi sampel, uji aktivitas larvasida, dan uji toksisitas. Pada ujifitokimia, pengujian fitokimia pada penelitian ini dapat membuktikan secara nyata kandungan metabolit sekunder dalam sampel bunga jantan kluwih. [31]
Menurut Depkes (2008), bunga jantan kluwih mengandung tanin, saponin, triterpenoid, alkaloid, dan flavonoid. Pada penelitian, hasil uji fitokimia terhadap sampel kering diperoleh hasil positif untuk uji tanin, saponin, dan triterpenoid. Namun, pada uji spesifik terhadap flavonoid dan alkaloid didapatkan hasil yang negatif. Flavonoid seharusnya positif pada sampel, karena pada umumnya tumbuhan yang termasuk tingkat tinggi mengandung flavonoid. Hasil yang negatif dapat disebabkan karena adanya proses pembusukkan, karena sampel yang diambil merupakan limbah bunga jantan kluwih yang telah jatuh. Proses pembusukan ini dapat terjadi selama bunga jantan kluwih berada di pohonnya sampai jatuh, atau proses pembusukkan setelah bunga jantan kluwih jatuh. Pembusukan terjadi secara enzimatis, sehingga terjadi proses degradasi yang menyebabkan adanya perubahan komponen yang terjadi pada sampel. ${ }^{[31]}$

Sedangkan untuk uji toksisitas didapatkan hasil bahwa ekstrak bunga jantan kluwih aman digunakan berdasarkan uji toksisitas Brain Shrimp Lethal Toxicity (BSLT) dengan menggunakan larva udang, karena tidak bersifat toksik.[31]

Bunga kluwih mengandung senyawa-senyawa seperti saponin, flavonoid, polifenol, yang memiliki efek mekanisme berurutan yaitu penghambat rangsang makan serangga, inhibitor pernafasan, hormon penghambat moulting. Saponin yang mempunyai efek menurunkan tegangan permukaan sehingga merusak membran sel dan mengaktifkan enzim serta merusak protein sel. Kandungan kimia bunga kluwih yang lain yang berfungsi sebagai insektisidal adalah polifenol dan flavonoid. [26]

Penelitian-penelitian saat ini yang membahas mengenai efektifitas bunga kamboja maupun bunga kluwih sebagai biolarvasida memang masih hanya terfokus pada larva Aedes aegypti saja, akan tetapi bunga kamboja maupun bunga kluwih menunjukan potensi bisa digunakan sebagai biolarvasida Anopheles sp. 


\section{KESIMPULAN}

Berdasarkan

pemaparan tersebut, disimpulkan kombinasi ekstrak bunga kamboja (Plumeria sp.) dan bunga kluwih (Artocarpus camansi) memiliki potensi untuk digunakan sebagai biolarvasida nyamuk Anopheles. Hal ini terjadi karena pada ekstrak bunga Plumeria sp. menunjukkan adanya steroid, alkaloid, flavonoid, glikosida, tanin dan karbohidrat. Senyawa steroid, flavonoid, dan alkaloid merupakan beberapa senyawa aktif yang diperkirakan memiliki efek larvisida. Sedangkan bunga kluwih mengandung senyawa-senyawa seperti saponin, flavonoid, polifenol, yang memiliki efek mekanisme berurutan yaitu penghambat rangsang makan serangga, inhibitor pernafasan, hormon penghambat moulting. Sehingga apabila kedua bunga ini dikombinasikan berpotensi memiliki efek larvasida yang semakin efektif.

\section{DAFTAR PUSTAKA}

1. WHO. World Malaria Report, 2018.

2. Ditjen Pencegahan dan Pengendalian Penyakit. Buku Saku Penatalaksanaan Kasus Malaria, Kemenkes RI, Jakarta, 2017.

3. Suwito, Hadi UK, Sigit SH, Sukowati S. Hubungan Iklim, Kepadatan Nyamuk Anopheles dan Kejadian Penyakit Malaria, Jurnal Entomologi Indonesia 2010; 7(1): 42-53.

4. Kementerian Kesehatan RI Epidemiologi Malaria di Indonesia, Buletinn Jendela Data dan Informasi Kesehatan, 2011.

5. WHO. World Malaria Report 2018 , WHO, USA, 2018.

6. U. N. D. Programme, Sustainable Development Goals, in Mengubah Dunia Kita: Agenda 2030 untuk Pembangunan Berkelanjutan, 2015.

7. WHO. Malaria and the Sustainable Development Goals for 2030, WHO, Swiss, 2018.

8. Lestari TRP. Pengendalian Malaria dalam Upaya Percepatan Pencapaian Target Millennium Development Goals, Jurnal Kesehatan Masyarakat Nasional 2012; 7(1): 22-30.
9. Kementerian Kesehatan Republik Indonesia, Situasi Terkini Perkembangan Program Pengendalian Malaria di Indonesia Tahun 2018, Jakarta, 2019.

10. Kementerian Kesehatan, InfoDATIN, 2016. Online. Available: www.kemkes.go.id. Accessed 14 September 2020.

11. Bappenas, Rencana Pembangunan Jangka Menengah Nasional IV 2020-2024, Indonesia Berpenghasilan Menengah- Tinggi yang Sejahtera, Adil, dan Berkesinambungan; 4: 315.

12. Gautam K, Kumar P, Poonia S, Larvicidal activity and GC-MS analysis of flavonoids of Vitex negundo and Andrographis paniculata against two vector mosquitoes Anopheles stephensi and Aedes aegypti., J Vector Borne Disease 2013; 50: 171-178.

13. Kasai $S$, Komagata $O$ and Itokawa $\mathrm{K}$, et al., Mechanisms of Pyrethroid Resistance in the Dengue Mosquito Vector, Aedes aegypti: Target Site Insensitivity, Penetration, and Metabolism, PLOS Neglected Tropical Diseases 2014; 8(6).

14. Widiastuti D, Ikawati B. Malathion Resistance And Esterase Enzyme Activity Of Aedes aegypti Population In Pekalongan Regency, BALABA 2016; 12(2): 61-70.

15. Anindita R, Kesetyaningsih TW. Resistance Detection on Aedes aegypti Larvae in Bantul District, Yogyakarta Using A Biochemical Assay Based on The Activity of Esterase Enzyme, Mutiara Medika Edisi Khusus 2007; 7(2): 88-94.

16. Rehman H, Aziz AT, Saggu S, Abbas ZK, Mohan A, Ansari AA. Systematic review on pyrethroid toxicity with special reference to deltamethrin, Journal of Entomology and Zoology Studies 2014; 2(6): 6070.

17. Sutarto, Syani AY. Resistensi Insektisida pada Aedes aegypti, $J$ Agromedicine Unila 2018; 5(2): 582586.

18. Yahouédo GA, Chandre $F$, Rossignol M, Ginibre C, 
Balabanidou V, Mendez NGA, Pigeon $\mathrm{O}$, et al. Contributions of cuticle permeability and enzyme detoxification to pyrethroid resistance in the major malaria vector Anopheles gambiae., Scientific reports 2007; 7.

19. Nwane $P$, Etang J, Chouaibou M, Toto JC, Koffi A, Mimpfoundi R, et al. Multiple insecticide resistance mechanisms in Anopheles gambiae s.l. populations from Cameroon, Central Africa, Parasit vectors 2013; 6(41).

20. Musfirah, Pengendalian Kimia dan Resistensi Vektor Anopheles Dewasa pada Kawasan Endemis Malaria di Dunia, Jurnal Fakultas Kesehatan Masyarakat 2017; 11(1): 46-51.

21. V. I. LushChak, T. M. Matviishyn, V. V. Husak, J. M. Storey and K. B. Storey, Pesticide toxicity: a mechanistic approach, EXCLI Journal Experimental and Clinical Sciences 2018; 1101-1136.

22. E. S. Cha , Y. H. Khang and W. J. Lee, Mortality from and Incidence of Pesticide Poisoning in South Korea: Findings from National Death and Health Utilization Data between 2006 and 2010, PLOS ONE 2014; 9(4).

23. G. K. Uggini, P. V. Patel and S. Balakrishnan, Embryotoxic and Teratogenic Effects of Pesticides in Chick Embryos: A Comparative Study Using Two Commercial Formulations, Environmental Toxicology 2012; 27(3): 166-174.

24. K. Gautam, P. Kumar and S. Poonia, Larvicidal activity and GCMS analysis of flavonoid of Vitex negundo and Andrographis paniculata against two vector mosquitoes Anopheles stephensi and Aedes aegypti, Journal of Vector Borne Disease 2013; 50: 171-178, 2013.

25. Z. Zaheer, A. G. Konale, K. A. Patel, S. Khan and R. Z. Ahmed, Comparative phytochemical screening of flowers of plumeria alba and plumeria rubra, Asian Journal of Pharmaceutical and Clinical Research 2010; 3(4).

26. F. Nikmah, S. and R. Hestiningsih, Potensi ekstrak bunga kluwih (Artocarpus altilis linn) sebagai insektisida terhadap kematian nyamuk aedes aegypti linn dengan metode elektrik cair, Jurnal Kesehatan Masyarakat 2016; 4(1).

27. Dey A, Mukherjee A. Plumeria rubra $L$ : Ethnobotany, Phytochemistry and Pharmacology, Journal of Plant Sciences 2015; 10(2): 54-62.

28. Rahayuningrum DN. Efektivitas Ekstrak Daun Kamboja (Plumeria acuminata Ait.)Sebagai Biolarvasida Nyamuk Aedes aegypti L, Universitas Nusantara PGRI Kediri, Kediri, 2018.

29. Divinadia YD. Efektivitas Larvisida Ekstrak Etanol Bunga Kamboja Putih (Plumeria acuminate, W.T.Ait) Terhadap Aedes Sp, Universitas Kristen Maranatha, Bandung, 2016.

30. Farooque AMD, Mazumder A, Shambhawee $S$ et al. Review on plumeria acuminata, International Journal of Research in Pharmacy and Chemistry, 2012.

31. A. H. Mulyati, D. Widiastuti and P. S. Ratih, Pemanfaatan Limbah Bunga Jantan Kluwih Sebagai Larvasida Nyamuk Aedes Aegypti, Ekologia 2014; 14(2): 10-16.

32. Pusat Data dan Informasi Kemenkes RI, Malaria Children's Literature in Education, Kemenkes RI, 2016. 